УДК 37.017.4:172.12-047.22

DOI: 10.37026/2520-6427-2021-107-3-122-126
Лариса ПАНІНА,

кандидат історичних наук,

доцент кафедри суспільно-гуманітарної освіти

Рівненського обласного інституту

післядипломної педагогічної освіти,

м. Рівне, Україна

ORCID: 0000-0001-6692-1409

e-mail: larisapanina600@gmail.com

Лілія АВДИМИРЕЦЬ,

стариий викладач кафедри

суспільно-гуманітарної освіти

Рівненського обласного інституту

післядипломної педагогічної освіти,

м. Рівне, Україна

ORCID: 0000-0003-3567-952X

e-mail: avdumuretslilia@gmail.com

\title{
ФОРМУВАННЯ ГРОМАДЯНСЬКОЇ ВІДПОВІДАЛЬНОСТІ ЯК СКЛАДОВОЇ ГРОМАДЯНСЬКОЇ КОМПЕТЕНТНОСТІ ЗДОБУВАЧІВ ОСВІТИ ЗАКЛАДУ ЗАГАЛЬНОЇ СЕРЕДНЬОЇ ОСВІТИ
}

\begin{abstract}
Анотація. У статті розглянуто питання формування громадянської відповідальності як складової громадянської компетентності в здобувачів освіти закладу загальної середньої освіти. Здійснено аналіз нормативних та наукових джерел, розкрито поняття громадянської, соиіальної компетентності та громадянської відповідальності. Громадянську і сочіальну компетентності визначено як ключові компетентності Нової украӥнськоі школи. Проаналізовано методи, щзо сприяють формуванню громадянської відповідальності та громадянської позииії учнів у закладу загальної середньої освіти. Визначено сутнісні характеристики
\end{abstract}

громадянської відповідальності особистості та взаємозв'язок $і$ взаємообумовленість громадянської відповідальності із соиіально-духовним становленням особистості. Проаналізовано чинники, які мають вплив на становлення громадянської відповідальності здобувачів освіти закладу загальної середньої освіти.

Ключові слова: громадянська компетентність, громадянськість, громадянські иінності, громадянська відповідальність, відповідальний громадянин, громадянська свідомість, громадянська позиџія, здобувачі освіти, громадянська освіта, демократичне суспільство.

\author{
Larysa PANINA, \\ Candidate of Historical Sciences, \\ Head of the Department of Social and \\ Humanitarian Education, \\ Rivne Regional Institute \\ of Postgraduate Pedagogical Education, \\ Rivne, Ukraine \\ ORCID: 0000-0001-6692-1409 \\ e-mail: larisapanina600@gmail.com \\ Lilia AVDYMYRETS, \\ Senior lecturer of the Department of \\ Social and Humanitarian Education, \\ Rivne Regional Institute \\ of Postgraduate Pedagogical Education, \\ Rivne, Ukraine \\ ORCID: 0000-0003-3567-952X \\ e-mail:avdumuretslilia@gmail.com
}




\section{DEVELOPMENT OF CIVIC RESPONSIBILITY AS A COMPONENT OF CIVIC COMPETENCE OF STUDENTS OF GENERAL SECONDARY EDUCATION}

\begin{abstract}
The article is concerned with development of civic responsibility as a component of civic competence of students of general secondary education.

The author analyzes informative and scientific sources and explains the concepts of civic and social competence and civic responsibility. Especially it has been noted that civic and social competences are key competences of the New Ukrainian School.

According to the framework of renewed key competences for lifelong learning I has been outlined the basic knowledge, skills and attitudes related to civic competence. The main components of civic competence, including civic responsibility are highlighted. The author defines main features of civic responsibility of the individual and shows the relationship and interdependence of civic responsibility with the spiritual and social development of the individual.
\end{abstract}

The paper analyzes the factors that facilitate the development of civic responsibility of students of general secondary education. The importance of education in the formation and development in youth civic values, necessary for active participation in a democratic society, is described.

The article deals with methods that influence the development of civic responsibility and civic position of young people.

The author emphasizes the necessity to raise a good citizen of Ukraine as an educated, creative person, who organically combines high moral traits, civic maturity, patriotism and the need for self-improvement.

Key words: civic competence, civic awareness, civic values, civic responsibility, responsible citizen, civic consciousness, civic position, students, civic education, democratic society.

Постановка проблеми. Одним із актуальних завдань сучасної освіти і виховання в Україні є створення умов для формування людини-громадянина, для якої демократичне громадянське суспільство - осередок для розкриття творчих можливостей, задоволення особистих та суспільних інтересів. Саме це може забезпечити система громадянської освіти, покликана підготувати молодь до активної участі в житті демократичного суспільства і формування іiї громадянської компетентності (Державний стандарт базової і повної загальної середньої освіти, 2020).

Успішна держава формується з відповідальних, чесних, толерантних та успішних громадян, а європейське майбутнє України залежить не тільки від політиків чи дипломатів. Бути громадянином - це не лише мати права, а передусім бути відповідальним, адже саме громадяни відповідають за долю своєї держави, за зміни й модернізаційні процеси, що відбуваються в ній. До роботи у цьому напрямі має долучитися як суспільство загалом, так і кожен його громадянин зокрема.

Зміни, що відбуваються в сучасній освіті, спонукають нас до розуміння важливості цінностей громадянської освіти. Усе більше звертаємося до понять, що лежать в основі побудови навчання на цінностях: «відповідальність», «рівність», «права людини», «демократія», «повага до різноманіття», «повага до людської гідності». Усе глибше обговорюємо їхнє практичне значення й користь, приходимо до спільного розуміння їхньої сутності, усвідомлюємо, чому вони важливі для кожного громадянина, кожної громадянки. Одним із основних понять Концепції «Нова українська школа» стає поняття компетентності (Закон України «Про освіту», 2017).

До числа ключових фахівці відносять і компетентність у сфері громадянської діяльності та цінностей, що $є$ одним із вимірів практичної переорієнтації української освіти. 3 огляду на це, стратегічним пріоритетом загальної середньої освіти мають стати не тільки передача знань, формування умінь і навичок, підготовка учнів до життя і праці, а й виховання в них громадянської відповідальності як важливої особистісної якості, як складової громадянської компетентності. Виклики, пов'язані з формуванням активного та відповідального громадянина з високим почуттям власної гідності, стійкою громадянською позицією, готовністю до виконання громадянських обов'язків, потребують комплексного підходу до вирішення поставлених завдань в умовах модернізації української освіти. Зважаючи на це, переконані, що порушена нами в статті проблема $є$ неабияк актуальною в умовах створення сучасного освітнього середовища.

Аналіз наукових досліджень і публікацій. Різноманітні аспекти питання громадянської компетентності представлені в працях як вітчизняних, так і зарубіжних науковців. Сутність та умови формування громадянської компетентності особистості досліджували А. Маркова, В. Столін, О. Овчарук, О. Пометун, Т. Ремех, О. Шестопалюк, Є. Мединський, А. Гаязов, І. Доліна, В. Журова, Ю. Підлісна, В. Степаненко та ін. Зокрема, О. Пометун та О. Шестопалюк у своїх роботах визначають зміст і структуру, умови формування громадянської компетентності сучасної молоді, яка забезпечує формування свідомого громадянина, патріота, професіонала, тобто людину, якій притаманні особистісні якості й риси характеру, світогляд і спосіб мислення, почуття, вчинки та поведінка, спрямовані на саморозвиток та розвиток демократичного громадянського суспільства в Україні (Пометун, Гупан, 2008; Шестопалюк, 2009). 3 упровадженням компетентнісного навчання в сучасну освіту провідні науковці звертають увагу на питання формування громадянської компетентності учнів закладу загальної середньої освіти. Так, А. Гаязов, І. Доліна, В. Журова присвятили свої розвідки вивченню педагогічних умов формування громадянської компетентності здобувачів освіти, а Т. Ремех дослідила сутність і структуру громадянської компетентності учнів закладів загальної середньої освіти відповідно до оновлення нормативної бази та стандартів освіти. 
Питання громадянського та патріотичного виховання, активної громадянської позиції, громадянської відповідальності й громадянськості як особистісної характеристики простежуються в роботах I. Беха, М. Боришевського, Г. Ломакіної, В. Муздибаєва, Г. Назаренка, Л. Савсарової, Л. Снігур, О. Сухомлинської, О. Фурман.

Серед зарубіжних дослідників варто виокремити Р. Голлоба, П. Крапфа, Д. Роу, В. Таелмана, Т. Хаддлестона, які систематизують та аналізують інтегральний підхід до освіти для демократичного громадянства, виокремлюють три дидактичні підходи до неї: навчання «про демократію та права людини», навчання «через демократію та права людини», навчання «для демократії та прав людини».

Визначенню та реалізації мети формування громадянської відповідальності як складової громадянської компетентності здобувачів освіти сприяють ухвалені державні документи (Закон України «Про освіту» (2017), Концепція «Нова українська школа» (2016), Державний стандарт базової середньої освіти (2020), Концепція розвитку громадянської освіти в Україні (2018)), а також міжнародні нормативи (Рамкова програма ЄС щодо оновлених ключових компетентностей (2018), Хартія Ради Європи з освіти з демократичного громадянства й освіти 3 прав людини (2010), Компетентності для культури демократії (2016)), що визначають стратегічну спрямованість у громадянському й національно-патріотичному вихованні учнівської молоді, окреслюють сутність поняття «громадянська компетентність» та іiї структурну характеристику.

Аналіз представлених наукових досліджень свідчить, що більшість наявних розвідок присвячені формуванню громадянської компетентності в процесі навчання і ми вважаємо, що формування громадянської відповідальності як складової громадянської компетентності є однією з ключових компетентностей Нової української школи, а отже, потребує грунтовного дослідження.

Мета статті - обгрунтувати ефективність процесу формування громадянської компетентності здобувачів освіти; визначити основні акценти щодо формування громадянської компетентності; окреслити сутнісні характеристики громадянської відповідальності як складової громадянської компетентності для створення освітнього громадянського середовища Нової української школи.

Виклад основного матеріалу дослідження. Стати успішною людиною сьогодні, в епоху змін і перетворень, - означає набути компетентностей у різних сферах: політичній, економічній, духовній, соціальній тощо. Повноцінне формування компетентностей можливе лише за умови запровадження компетентнісного підходу до навчання, під яким розуміється спрямованість усього освітнього процесу на формування і розвиток компетентностей особистості, відбір відповідного змісту навчання, варіанта його організації та способу оцінювання результатів і якості (Концепція «Нова українська школа», 2016) .

Громадянська компетентність - одна 3 ключових компетентностей, закладених у Законі України «Про освіту», Концепції «Нова українська школа», а також
Державному стандарті базової середньої освіти, де зазначено, що громадянські та соціальні компетентності пов'язані з ідеями демократії, справедливості, рівності, прав людини, добробуту та здорового способу життя, з усвідомленням рівних прав і можливостей, що передбачають:

- здатність діяти як відповідальний громадянин, брати участь у громадському та суспільному житті, зокрема закладу освіти та класу, спираючись на розуміння загальнолюдських і суспільних цінностей, соціальних, правових, економічних і політичних принципів, ідей сталого розвитку суспільства, співіснування людей та спільнот у глобальному світі, критичне осмислення основних подій національної, європейської та світової історії, усвідомлення їхнього впливу на світогляд громадянина та його самоідентифікацію;

- виявлення повагу до інших, толерантність, уміння конструктивно співпрацювати, співпереживати, долати стрес і діяти в конфліктних ситуаціях, зокрема пов'язаних із різними проявами дискримінації; дбайливе ставлення до особистого, соціального здоров'я, усвідомлення особистих відчуттів і почуттів, здатність дослухатися до внутрішніх потреб; дотримання здорового способу життя; розуміння правил поведінки та спілкування, що є загальноприйнятими в різних спільнотах і середовищах та грунтуються на спільних моральних цінностях; спроможність діяти в умовах невизначеності та багатозадачності (Державний стандарт базової середньої освіти, 2020).

Таким чином, під громадянською компетентністю розумітимемо інтегративну, особистісно орієнтовану якість особистості, яка дозволяє їй свідомо, відповідально й ефективно користуватися громадянськими правами й свободами, виконувати обов'язки громадянина суспільства, мати активну громадянську позицію, володіти системою громадянських цінностей.

У зв'язку з цим О. Пометун відзначає, що громадянська компетентність $є$ інтегративною характеристикою особистості, що включає й певний рівень психологічної готовності до здійснення суспільного життя - громадянськості (Пометун, 2005).

Громадянськість $є$ важливим поняттям в особистісній характеристиці сучасної учнівської молоді. Громадянськість - це моральна позиція, що виражається в почутті обов'язку і відповідальності людини перед громадянським суспільством, до якого вона належить, у готовності відстоювати його інтереси і захищати від будь-яких зазіхань на його права. До складових громадянськості Є. Мануйлов відносить: громадянські знання, громадянську відповідальність, громадянську компетентність, громадянський обов'язок, громадянську справедливість, громадянську рівність та свободу, громадянську свідомість тощо (Мануйлов, 2014).

Отже, громадянські компетентності є здатністю людини захищати та піклуватися про права, інтереси та потреби людини і громадянина, держави й суспільства. Вони повинні формуватися із наймолодшого віку, аби дитина могла самостійно та свідомо визначати та формувати власну поведінку. Одним зі складових $\epsilon$ навчання права власного вибору, яке підсилюється розумінням відповідальності власних вчинків.

Громадянська відповідальність - це свідоме ставлення особистості як члена суспільства до його 
вимог, уміння відповідати за власне життя, дії, вчинки. Ознаками громадянської відповідальності особистості $\epsilon$ активна життєва позиція, усвідомлене ставлення до виконання свого громадянського обов'язку, самостійність та наполегливість, самоаналіз, самоконтроль, самоорганізація, чесність, готовність відповідати за власні вчинки тощо (Концепція «Нова українська школа», 2016). У ній інтегровані утворення свідомості та самосвідомості, а також взаємно поєднані такі компоненти, як когнітивний, емоційно-мотиваційний, поведінково-вольовий, морально-духовний (Онопрієнко, 2007). І. Бех, характеризуючи громадянина як патріота своєї держави, називає почуття громадянської відповідальності та обов'язку одним із першочергових якостей особистості (Бех, 1998).

Більшість науковців співвідносять поняття громадянської відповідальності як складової громадянської компететнтності з громадянською діяльністю, готовністю особистості до участі у суспільно-політичних процесах, поінформованістю (Ремех, 2018).

Свій перший досвід суспільного життя, конструктивної взаємодії з іншими здобувачі освіти отримують у закладах освіти, тож вкрай важливо, щоб цей досвід формував активну громадянську позицію, відповідальне ставлення до виконання громадянських обов'язків.

Щоб стати відповідальними, сумлінними, активними громадянами, здобувачі освіти мають володіти такими навичками: формулювати, комунікувати й відстоювати власну думку, бути толерантними, впевненими в собі, готовими діяти в ситуації невизначеності, співпрацювати з різними людьми з різними віросповіданнями, поважати себе та інших. Такі знання, навички і ставлення дають змогу учням готуватися i бути готовими до незалежного, відповідального життя, виваженого прийняття доцільних рішень і злагодженої взаємодії у спільноті - класі, школі, місцевій громаді, колективі, державі.

Означені компоненти громадянської компетентності формуються комплексно, тобто комплексне поєднання освітніх заходів, практичний досвід здобувачів освіти дозволить створити дієвий громадянський освітній простір Нової української школи.

У процесі формування громадянської відповідальності як складової громадянської компетентності важливо спиратися на загальношкільний підхід, пропагований зусиллями Ради Європи та Європейського центру ім. Вергеланда, який передбачає:

- наскрізну інтеграцію демократичних принципів і цінностей в усі шкільні предмети;

- орієнтацію всього освітнього процесу на розвиток компетентностей для життя в демократичному суспільстві;

- побудову партнерських стосунків між школою, батьками та громадою, залучення всіх учасників освітнього процесу до ухвалення рішень (Громадянська відповідальність, 2017, с. 6).

Такий підхід передбачає міжпредметну взаємодію під час реалізації змісту навчання, а також зміни в організації діяльності закладу освіти, вимагає спільних зусиль усіх учасників освітнього процесу.

Серед видів і засобів, методів і форм формування громадянської відповідальності як складової громадянських і соціальних компетентностей пріо- ритетна роль належить активним методам, які грунтуються на рівності позицій та взаємодії здобувачів освіти, що спрямовані на відповідальний, самостійний пошук істини і сприяють формуванню критичного мислення, ініціативності, творчості, пізнавального інтересу. До таких методів належать: метод проєктів, ситуаційно-рольові ігри, соціограма, метод відкритої трибуни, інтелектуальні аукціони, мозкові штурми, метод аналізу соціальних ситуацій із морально-етичним характером, ігри-драматизації тощо.

Таким чином, громадянська відповідальність особистості, формування якої відбувається в процесі іiї соціалізації та під впливом низки чинників, як-от: політико-правова система держави, загальний рівень морально-правової культури суспільства, особливостей родинних та міжособистісних стосунків тощо, формується на базі громадянської компетентності та $є$ її складовою, що дозволяє активно й ефективно реалізовувати громадянські права й обов'язки, зміцнювати ціннісні підвалини існування демократичного суспільства.

Висновки. Отже, реформування української школи вимагає нових підходів до освітнього процесу. За таких умов одним із найбільших викликів $є$ створення демократичного громадянського середовища для навчання й виховання дітей на основі цінностей демократії і прав людини. Саме тому важливими є питання щодо формування громадянської відповідальності як складової громадянської компетентності, іiї критеріїв, стандартів, часу, який потрібен для іiі формування, а все загалом потребує цілеспрямованих зусиль влади, освіти, широких кіл української громадськості.

Перспективи подальших досліджень у даному напрямі спрямовані на розробку та впровадження в практику освітньої діяльності закладів загальної середньої освіти технологій формування громадянської відповідальності як складової громадянської компетентності здобувачів освіти для створення освітнього громадянського середовища Нової української школи.

\section{СПИСОК ВИКОРИСТАНОЇ ЛІТЕРАТУРИ}

Державний стандарт базової середньої освіти. (2020). URL: https://mon.gov.ua/ua/osvita/zagalna-serednya-osvita/ nova-ukrayinska-shkola/derzhavnij-standart-bazovoyiserednoyi-osviti (дата звернення: 05.06.2021).

Про освіту: Закон України від 05.09.2017 р. № 2145-VIII. URL: https://zakon.rada.gov.ua/laws/show/2145-19\#Text (дата звернення: 05.06.2021).

Пометун, О., Гупан, Н. (2008). Формування громадянської компетентності старшокласників у процесі навчання історії. Історія в школах України. № 4. С. 3-10.

Шестопалюк, О. В. (2009). Розвиток громадянської компетентності майбутніх вчителів: монографія. Вінниця: Консоль. 312 с.

Концептуальні засади реформування середньої школи «Нова українська школа». (2016). URL: https:// www.kmu.gov.ua/storage/app/media/reforms/ukrainskashkolacompressed.pdf (дата звернення: 05.06.2021).

Пометун, О. (2005). Формування громадянської компетентності: погляд з позиції сучасної педагогічної науки. Вісник програм шкільних обмінів. № 23. С. 5-9. 
Мануйлов, Є. М. (2014). Проблема відповідальності особистості в контексті моралі. Вісник Національного університету «Юридична академія України імені Ярослава Мудрого». Серія «Філософія, філософія права, політологія, соиіологія). № 1. С. 29-35.

Онопрієнко, О. (2007). Концептуальні засади компетентнісного підходу в сучасній освіті. Шлях освіти. № 4. C. 32-37.

Бех, І. Д. (1998). Психолого-педагогічні умови виховання в молоді громадянськості. Громадянське виховання молоді в умовах трансформації суспільства: зб. наук. статей. Черкаси. С. 3-6.

Ремех, Т. (2018). Сутність і структура громадянської компетентності учня Нової української школи. Украйнський педагогічний журнал. № 2. С. 34-40.

Громадянська відповідальність: 80 вправ для формування громадянської та соціальної компетентностей під час вивчення різних шкільних предметів. 5-9 клас. Посібник для вчителя. (2017) / М. Рафальська, О. Боярчук, Н. Герасим та ін. Харків: Вид. група «Основа». 136 c. URL: https://www.schools-for-democracy.org/images/ documents/71/gromadyanska_vidpovidalnist_ua.pdf (дата звернення: 12.06.2021).

\section{REFERENCES}

Derzhavnyi standart bazovoi serednoi osvity [State Standard of Basic Secondary Education]. (2020). URL: https://mon.gov.ua/ua/osvita/zagalna-serednya-osvita/nova-ukrayinska-shkola/derzhavnij-standart-bazovoyi-serednoyi-osviti (data zvernennia: 05.06.2021). [in Ukrainian].

Pro osvitu: Zakon Ukrainy [Law of Ukraine «On Education»]: vid 05.09.2017 r. № 2145-VIII. URL: https://zakon.rada.gov.ua/laws/show/2145-19\#Text (data zvernennia: 05.06.2021). [in Ukrainian].

Pometun, O., Hupan, N. (2008). Formuvannia hromadianskoi kompetentnosti starshoklasnykiv u protsesi navchannia istorii [Development of civic competence of upper secondary school pupils in history lessons]. Istoriia $v$ shkolakh Ukrainy. № 4. S. 3-10. [in Ukrainian].

Shestopaliuk, O. V. (2009). Rozvytok hromadianskoi kompetentnosti maibutnikh vchyteliv [Development of civic competence of future teachers]: monohrafiia. Vinnytsia: Konsol. 312 s. [in Ukrainian].
Kontseptualni zasady reformuvannia serednoi shkoly «Nova ukrainska shkola» [Conceptual principles of secondary school reform «New Ukrainian school»]. (2016). URL: https://www.kmu.gov.ua/storage/app/media/reforms/ukrainska-shkolacompressed.pdf (data zvernennia: 05.06.2021). [in Ukrainian].

Pometun, O. (2005). Formuvannia hromadianskoi kompetentnosti: pohliad z pozytsii suchasnoi pedahohichnoi nauky [Development of civic competence from the point of view of modern pedagogy]. Visnyk prohram shkilnykh obminiv. № 23. S. 5-9. [in Ukrainian].

Manuilov, Ye. M. (2014). Problema vidpovidalnosti osobystosti $\mathrm{v}$ konteksti morali. [Personal responsibility in the context of morality]. Visnyk Natsionalnoho universytetu "Iurydychna akademiia Ukrainy imeni Yaroslava Mudroho». Seriia "Filosofia, filosofia prava, politolohiia, sotsiolohiia». № 1. S. 29-35. [in Ukrainian].

Onopriienko, O. (2007). Kontseptualni zasady kompetentnisnoho pidkhodu v suchasnii osviti [Competency based approach in modern education]. Shliakh osvity. № 4. S. 32-37. [in Ukrainian].

Bekh, I. D. (1998). Psykholoho-pedahohichni umovy vykhovannia v molodi hromadianskosti [Psychological and pedagogical conditionsfor the formation of civic awareness of youth]. Hromadianske vykhovannia molodi v umovakh transformatsii suspilstva: zb. nauk. statei. Cherkasy. S. 3-6. [in Ukrainian].

Remekh, T. (2018). Sutnist i struktura hromadianskoi kompetentnosti uchnia Novoi Ukrainskoi shkoly [Concept and structure of civic competence of the New Ukrainian School students]. Ukrainskyi pedahohichnyi zhurnal. № 2. S. 34 -40. [in Ukrainian].

Hromadianska vidpovidalnist: 80 vprav dlia formuvannia hromadianskoi ta sotsialnoi kompetentnostei pid chas vyvchennia riznykh shkilnykh predmetiv. 5-9 klasy. Posibnyk dlia vchytelia [Civic responsibility: 80 exercises for the development of civic and social competence in different school subjects. 5-9 grade. Teacher's book]. (2017) / M. Rafalska, O. Boiarchuk, N. Herasym ta in. Kharkiv: Vyd. hrupa «Osnova». 136 c. URL: https://www.schools-for-democracy. org/images/documents/71/gromadyanska vidpovidalnist ua.pdf (data zvernennia: 12.06.2021). [in Ūkrainian].

Дата надходження до редакиії: 13.07.2021 p. 